\title{
Development of Alternative Glass Ceramic Seal for a Planar Solid Oxide Fuel Cell
}

\author{
P. Lemes-Rachadel, ${ }^{1}$ H. Birol, ${ }^{1,2}$ A. P. N. Oliveira, ${ }^{1}$ and D. Hotza ${ }^{3}$ \\ ${ }^{1}$ Department of Mechanical Engineering (EMC), Federal University of Santa Catarina (UFSC), 88040-900 Florianópolis, SC, Brazil \\ ${ }^{2}$ CSEM Brasil Innovation Center, 30170-020 Belo Horizonte, MG, Brazil \\ ${ }^{3}$ Department of Chemical Engineering (EQA), Federal University of Santa Catarina (UFSC), 88040-900 Florianópolis, SC, Brazil
}

Correspondence should be addressed to D. Hotza, dhotza@gmail.com

Received 16 July 2012; Revised 12 September 2012; Accepted 29 September 2012

Academic Editor: Meilin Liu

Copyright ( $\odot 2012$ P. Lemes-Rachadel et al. This is an open access article distributed under the Creative Commons Attribution License, which permits unrestricted use, distribution, and reproduction in any medium, provided the original work is properly cited.

\begin{abstract}
LZSA glass ceramic $\left(\mathrm{LiO}_{2}-\mathrm{ZrO}_{2}-\mathrm{SiO}_{2}-\mathrm{Al}_{2} \mathrm{O}_{3}\right)$ was tested for its thermomechanical compatibility as a sealing material with a stainless steel interconnect (AISI 430) of a planar SOFC. With this purpose, the densification and crystallization behavior of LZSA were investigated initially. It was observed that the material reached maximum relative density and shrinkage, respectively $95 \%$ and $17 \%$, at $800^{\circ} \mathrm{C}$, which corresponded approximately to the crystallization temperature of the material as evidenced by DTA analysis. In the next step, LZSA tapes were cast from slurries and prepared either as LZSA laminates or LZSA-steel bilayers. The densification behavior and microstructural features of cofired LZSA laminates and LZSA-steel bilayers were analyzed at 800 and $900^{\circ} \mathrm{C}$. Maximum relative density and defect-free interfaces were observed for laminates and bi-layers cofired at $800^{\circ} \mathrm{C}$, whereas increased porosity and detached bi-layer were the characteristics of the samples fired at $900^{\circ} \mathrm{C}$.
\end{abstract}

\section{Introduction}

Seal is one of the most critical components of a SOFC as it prevents the mixture of the fuel and the oxidizing gas in the cell, fuel leakage from the stack, and the possibility of short circuit with the metallic interconnect [1-5]. Therefore, an ideal seal is expected to be hermetic, electrically insulating, thermomechanically and chemically compatible with other cell components at high temperatures and over long periods of time [1-9]. Glass ceramics are so far the most common seal materials, not only since they fulfill the aforementioned requirements but also due to their modifiable compositions, by which the critical properties such as glass transition temperature $\left(T_{g}\right)$, viscosity, coefficient of thermal expansion (CTE), and dielectric strength can be optimized [6-9].

Glass ceramic seals are a rigid type of seals, which are bonded to interconnector and electrodes by a chemical reaction unlike the compressive type of seals requiring an external force applied [1, 3, 9]. Therefore, adherence, cracking, and thermal expansion match are considered as the critical issues at the interfaces, which are strongly related to glass transition, crystallization, sintering temperatures $\left(T_{g}\right.$, $T_{c}, T_{s}$ ), and CTE of glass ceramic seals [3]. Ideally, the seal is expected to wet the surface after glass transition (or glass softening) temperature and to reach to full density prior to crystallization [3]. Crystallization preceding complete wetting or densification is extremely undesired as it results in poor adherence and porosity; whereas its insufficiency also results in lack of mechanical integrity of the seal that is enhanced by the crystalline phase $[3,8,9]$.

The major difficulty in developing glass ceramic seals for a specific application is the selection of proper glass composition, which is usually composed of network formers, network modifiers, and intermediate oxides [9]. Glass network formers are the main glass formers and the stable ones at/above $800^{\circ} \mathrm{C}$ are $\mathrm{SiO}_{2}, \mathrm{~B}_{2} \mathrm{O}_{3}$, or $\mathrm{P}_{2} \mathrm{O}_{5}$ [10]. Glass network modifiers are alkali metal oxides such as $\mathrm{Li}_{2} \mathrm{O}$, $\mathrm{Na}_{2} \mathrm{O}, \mathrm{K}_{2} \mathrm{O}$ and they increase the thermal expansion, while reducing the glass softening temperature of the glass [9]. They should, however, be selected with utmost attention as they react with other cell components due to their high diffusion coefficients at SOFC operation temperatures [9]. 


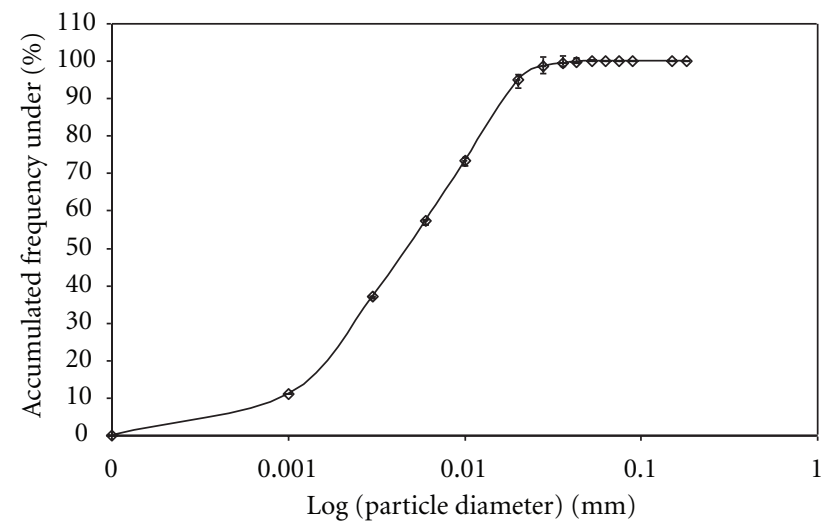

FIgURe 1: Particle size analysis of LZSA powder after ball milling for $144 \mathrm{~h}$.

Intermediate oxides are transition metal oxides such as $\mathrm{Fe}_{2} \mathrm{O}_{3}$ and $\mathrm{Cu}_{2} \mathrm{O}$, which enhance the bonding of the glass to the metal interconnector [9]. Typical glass ceramic seal materials are from the compositions of $\mathrm{X}$-aluminosilicates and $\mathrm{X}$ boroaluminosilicates (where $\mathrm{X}=\mathrm{Ba}, \mathrm{Mg}, \mathrm{Ca}, \mathrm{Sr}$ ) [2, 3], and barium calcium aluminosilicate [11].

Although the majority of glass ceramic seal compositions fall into one of the above mentioned groups and the alkaline glass network modifiers are not favored due to the aforesaid reasons, continuous efforts are in progress to prepare new compositions such as those including $\mathrm{ZnO}, \mathrm{LiO}_{2}[2,6,12]$. Considering the wider application areas that it has found recently [13-16] and to check its compatibility with AISI 430 stainless steel interconnector, the tape cast LZSA glass ceramic $\left(\mathrm{LiO}_{2}-\mathrm{ZrO}_{2}-\mathrm{SiO}_{2}-\mathrm{Al}_{2} \mathrm{O}_{3}\right)$ is tested in this article.

\section{Experimental}

The prepared LZSA glass powder [16] was initially ballmilled (Tecnal, TE 500) using alumina beads. The process was run continuously until an average particle size $\left(d_{50}\right)$ of $4.70 \pm 0.12 \mu \mathrm{m}$ (after three measurements) was reached after $144 \mathrm{~h}$ (Figure 1), which was measured by a laser particle size analyzer (Cilas 1064). The density of the powder $\left(2.71 \mathrm{~g} / \mathrm{cm}^{3}\right)$ was measured by a multipycnometer (Quantachrome MVP 4DC). The crystallization temperature $\left(T_{c}\right)$ of the powder was measured by a differential thermal analyzer (Netzsch, STA Jupiter) in air at $10^{\circ} \mathrm{C} / \mathrm{min}$ increments between 30 and $1000^{\circ} \mathrm{C}$.

Densification and shrinkage behaviors of LZSA were characterized by preparing cylindrical pellets, which were pressed in a hydraulic press (Danly, PH11) at $220 \mathrm{MPa}$ for $5 \mathrm{~min}$. Pressed pellets were fired in a muffle furnace (Jung J200) at different temperature (700, 750, 800, 850, $900^{\circ} \mathrm{C}$ ) and time $(60,120 \mathrm{~min})$ combinations (10 runs in total) to determine the sintering and shrinkage behavior. Four pellets per firing profile were prepared, weighed, and measured in radial and thickness directions prior to firing. They were heated at a rate of $1^{\circ} \mathrm{C} / \mathrm{min}$ from room temperature to the top firing temperature and a cooling rate of $10^{\circ} \mathrm{C} / \mathrm{min}$ from top temperature down to room

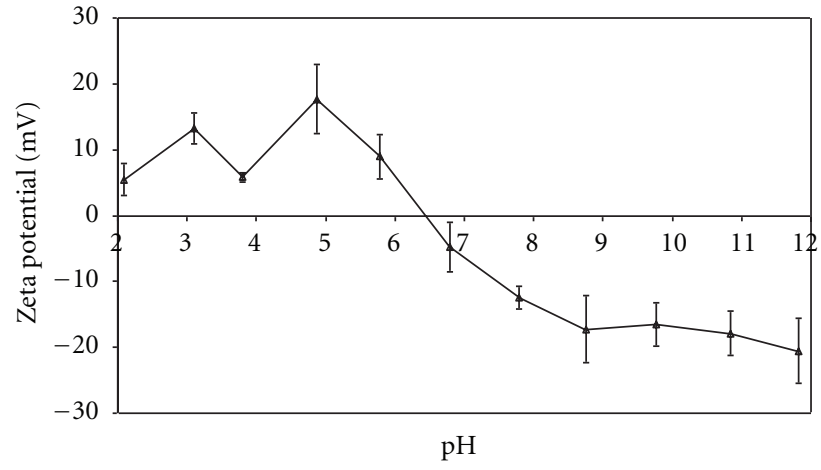

FIGURE 2: Zeta potential for LZSA, where IEP is at $\mathrm{pH}=6.46 \pm 0.23$.

temperature. The fired samples were then removed from the furnace, weighed, and dimensionally measured again and inserted into distilled water under vacuum for measuring the density by Archimedes's technique.

Additional pellets were also prepared identically and fired at 800,850 , and $900^{\circ} \mathrm{C}$ for $60 \mathrm{~min}$ for crystallographic characterization. The crystal phases formed were detected by an X-ray diffractometer (Philips Analytical PW-1830) using $\mathrm{CuK} \alpha$ radiation at $40 \mathrm{kV}$ and $40 \mathrm{~mA}$ between 13 and $70^{\circ}$ of $2 \theta, 0.02^{\circ}$ of step size, and 0.5 s per step. The ICDD data bank [17] was used for characterization of the crystalline phases formed.

LZSA tapes were cast by tape casting. Each slurry was composed of LZSA glass ceramic powder as the functional material, water-based acrylic binder (WB 4101, Polymer Innovations), deionized water as solvent and ammonium polyacrylate, PAA (Darvan 821A), as dispersant agent. Plasticizer and defoaming agents are reported to be in the binder formulation by producer. The components were mixed in a ball mill (Tecnal, TE 500) in two steps: initially, LZSA powder dried at $200^{\circ} \mathrm{C}$ for $2 \mathrm{~h}$, solvent, dispersant, and binder that is approximately $1.5 \%$ of powder weight (manufacturer's recommendation) were milled. In the next step, the necessary amount of binder was added and the mixture was remilled. Optimized stability and adequate rheological behavior of LZSA slurries were defined through design of experiments (DOE), according to a simple factorial $\left(2^{3}\right)$. The effects of three parameters were analyzed: (1) solids loading, ranging from 50 to $55 \mathrm{wt} \%$; (2) amount of binder in the second stage milling, varying between 20 and $24 \mathrm{wt} \%$; (3) time of milling in the range from 18 to $24 \mathrm{~h}$ for the first milling stage, and from 6 to $18 \mathrm{~h}$ for the second stage milling (Table 1 ).

After the second milling, $\mathrm{pH}$ was measured ( $\mathrm{PH}$ TEK, PHS-3B) and the rheological behavior of the slurries was analyzed using a rotational viscometer (Haake VT550). The measured viscosity of the slurries was found to fit to the Casson model [18] with a correlation coefficient of 0.99 . The stability of slurries was controlled by zeta potential analysis (Zetasizer ZEN3600, Malvern). The $\mathrm{pH}$ value of LZSA at the isoelectric point (IEP) was 6.46 \pm 0.23 (after three measurements), Figure 2.

The slurries exhibiting adequate rheological behavior and colloidal stability in addition to easy and reproducible 
TABLE 1: Design of experiments (DOE) for optimization of slurries.

\begin{tabular}{lcccc}
\hline Slurries & $\begin{array}{c}\text { Solids } \\
(\mathrm{wt} \%)\end{array}$ & $\begin{array}{c}\text { Binder } \\
(\mathrm{wt} \%)\end{array}$ & $\begin{array}{c}\text { 1st milling time } \\
(\mathrm{h})\end{array}$ & $\begin{array}{c}\text { 2nd milling time } \\
(\mathrm{h})\end{array}$ \\
\hline 1 & 50 & 20 & 18 & 6 \\
2 & 50 & 20 & 24 & 18 \\
3 & 50 & 24 & 18 & 6 \\
4 & 50 & 24 & 24 & 8 \\
5 & 55 & 20 & 18 & 6 \\
6 & 55 & 20 & 24 & 18 \\
7 & 55 & 24 & 18 & 6 \\
8 & 55 & 24 & 24 & 18 \\
\hline
\end{tabular}

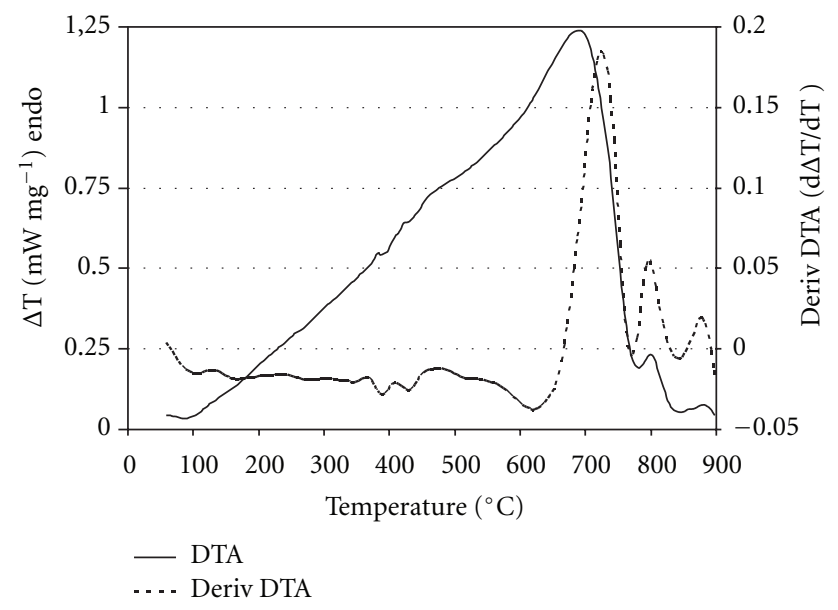

FIgURE 3: Differential thermal analysis (DTA) of LZSA.

casting were selected for tape casting. The slurries were deposited on a Mylar film by a tape caster (TCC-1200, Mistler) through a stationary doctor blade after de-airing (vacuum for $15 \mathrm{~min}$ ). The casting rate was $6 \mathrm{~cm} / \mathrm{min}$ to achieve a final thickness around $100 \mu \mathrm{m}$. Square tapes of $20 \mathrm{~mm} \times 20 \mathrm{~mm}$ were cut out from the identical position of the dried tapes for each one of the six compositions. They were laminated using a thermopress (Schultz, PTH 15) at $25 \mathrm{MPa}$ and $60^{\circ} \mathrm{C}$. The laminates were weighed and then fired in a muffle furnace (Jung J200). Four samples per tape composition were fired in two steps: (1) binder burn out by heating the samples at a rate of $0.5^{\circ} \mathrm{C} / \mathrm{min}$ from 30 to $350^{\circ} \mathrm{C}$ followed by a dwell time of $30 \mathrm{~min}$; (2) heating at a rate of $5^{\circ} \mathrm{C} / \mathrm{min}$ from $350^{\circ} \mathrm{C}$ to top firing temperatures, 800 and $900^{\circ} \mathrm{C}$, each followed by separate dwell times of 60 and $120 \mathrm{~min}$, respectively. The density of sintered samples was measured according to Archimedes's method.

After analyzing density values and SEM images of laminates, the ones exhibiting the highest quality (reproducible casting, high density, absence of surface, and interfaces defects) were selected for cofiring with stainless steel interconnect of $400 \mu \mathrm{m}$ thickness (AISI 430, Duferco). The lamination of LZSA single layer and interconnect was conducted according to the procedure mentioned previously for laminates. The bilayers were fired at 800 and $900^{\circ} \mathrm{C}$,
TABLE 2: Viscosity and $\mathrm{pH}$ values of prepared slurries.

\begin{tabular}{lcc}
\hline Slurries $^{\mathrm{a}}$ & ${\text { Viscosity }(\mathrm{mPa} \cdot \mathrm{s})^{\mathrm{b}}}$ & $\mathrm{pH}$ \\
\hline 1 & 1127 & 8.13 \\
2 & 2761 & 8.81 \\
3 & 2847 & 7.71 \\
4 & 3662 & 8.81 \\
5 & 1285 & 7.66 \\
6 & 2310 & 8.57 \\
\hline
\end{tabular}

${ }^{a}$ Slurries 7 and 8 were excluded due to extreme viscosity, making them impossible to cast.

${ }^{\mathrm{b}}$ At shear rate of $0.02-50 \mathrm{~s}^{-1}$, according to Casson's equation.

following identical firing conditions used for the laminates. In order to evaluate the thermomechanical compatibility of the LZSA/steel joint, their polished cross-sections were analyzed by SEM (JEOL, JSM-6390LV).

\section{Results and Discussion}

The crystallization temperature $\left(T_{c}\right)$ of LZSA was characterized by DTA (Figure 3). The derivative of the temperature difference $(\Delta T)$ as a function of temperature $(T)$ was calculated in order to distinguish the significant peaks indicating critical temperatures. The major peak in the derivative as well as in the DTA curves at $780 \pm 1{ }^{\circ} \mathrm{C}$ (after three measurements) was ascribed to the $T_{c}$ of the powder.

Sintering and shrinkage behavior of LZSA is presented in Figure 4. It can be seen that the samples reached a maximum relative density of $95 \%$ at $700^{\circ} \mathrm{C}$ and maintained this density up to $800^{\circ} \mathrm{C}$, where a maximum shrinkage of $17 \%$ was attained. The decrease in the values of these two quantities at higher temperatures was ascribed to crystallization in the range from 780 to $800^{\circ} \mathrm{C}$, which inhibited further densification and shrinkage by increasing the viscosity of the glass system [19].

Crystalline phases were analyzed by XRD of samples, which were fired at 800,850 , and $900^{\circ} \mathrm{C}$ for $60 \mathrm{~min}$ (Figure 5). Four phases were detected in the XRD patterns which are in accordance with former works on the same material [13-16]: lithium metasilicate $\left(\mathrm{Li}_{2} \mathrm{SiO}_{3}\right)$, zircon $\left(\mathrm{ZrSiO}_{4}\right)$, lithium aluminum silicate $\left(\mathrm{LiAlSi}_{3} \mathrm{O}_{8}\right.$, the predominant phase), and zirconium dioxide $\left(\mathrm{ZrO}_{2}\right.$, baddelyte). It was seen from the peak intensities that the increase of $\mathrm{ZrSiO}_{4}$ content was accompanied by consumption of $\mathrm{ZrO}_{2}$ at higher temperatures due to the reaction between $\mathrm{ZrO}_{2}$ and $\mathrm{SiO}_{2}$ of the residual glass phase, which showed that even after sintering (maximum densification) there was still a formation of crystals (around $850-900^{\circ} \mathrm{C}$ ) that may generate pores deriving from devitrification. This can be corroborated by the decrease in density and linear shrinkage at these temperatures as previously seen in Figure 4.

Table 2 shows the viscosity values modeled according to the Casson equation, which describes a pseudoplastic behavior independent of time, where the ratio between the shear stress and the shear rate decreases for an increase of the shear rate. This behavior is recommended for tape casting slurries since during casting the slurry should flow 


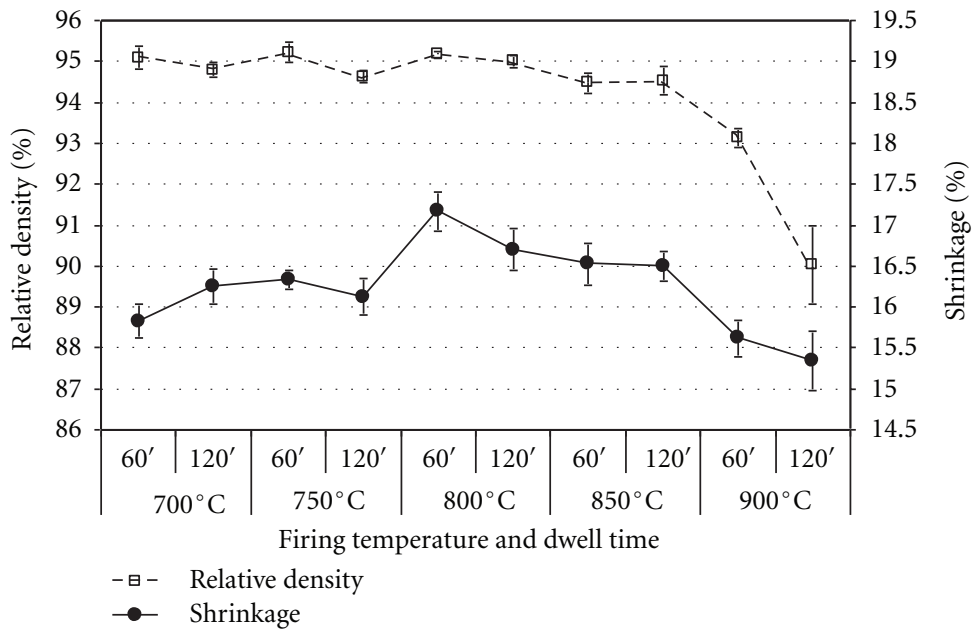

FIGURE 4: Relative density and shrinkage of LZSA as a function of different firing profiles.

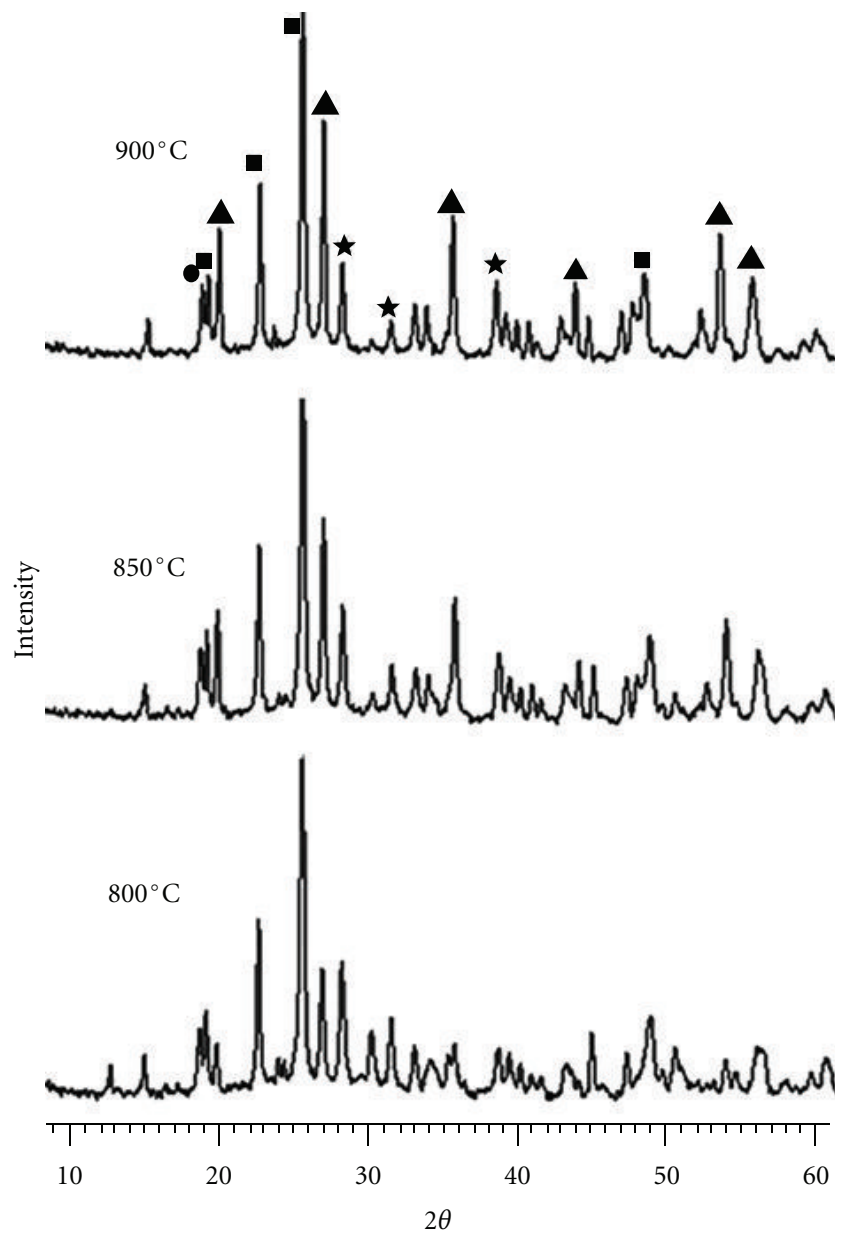

- Lithium metasilicate (70-0330)

\ Zirconium silicate $(83-1374)$

- Lithium aluminum silicate (35-0794)

Figure 5: Development of phases in LZSA as a function of temperature (all runs were made in $60 \mathrm{~min}$ ).

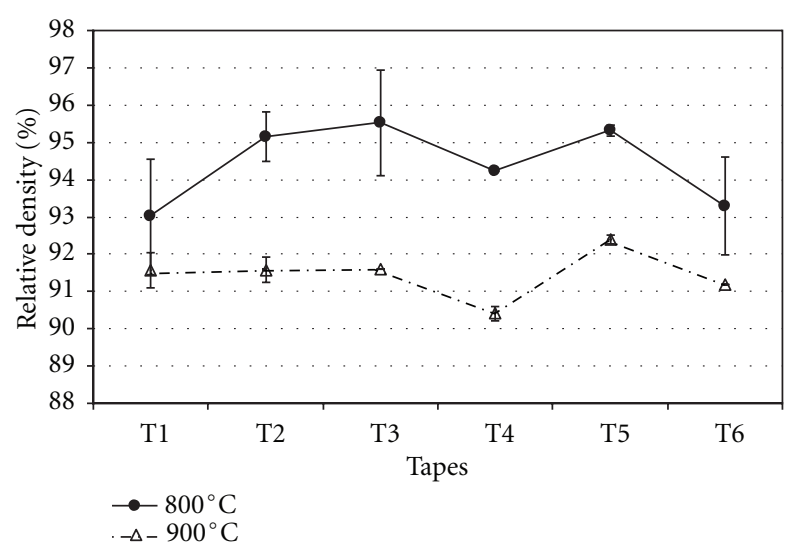

Figure 6: Densification of LZSA laminates prepared from different tapes at 800 and $900^{\circ} \mathrm{C}$.

easily under the doctor blade and immediately thereafter the viscosity should increase to keep the tape surface leveled and to avoid particle segregation before the solvent is released $[20,21]$. Slurries 1 to 6 showed adequate viscosity values for tape casting. On the other hand, slurries 7 and 8 were extremely viscous and not suitable for casting, and were excluded from further evaluation.

Table 2 presents the $\mathrm{pH}$ values measured after the second milling. The stability condition according to the zeta potential $(>10 \mathrm{mV})$ in the range of $\mathrm{pH}$ at the IEP and the actual $\mathrm{pH}$ of the slurry [22], corresponds to $\mathrm{pH}$ values over 7.5 , Figure 2. Thus, the prepared slurries were well dispersed at $\mathrm{pH}$ values ranging between 7.6 and 8.8.

The LZSA laminates were fired at 800 and $900^{\circ} \mathrm{C}$, the former being the temperature where maximum density and shrinkage were attained and the latter being within the operational temperature range of a high-temperature SOFC. Laminates reaching $95 \%$ relative density without delamination were obtained after firing at $800^{\circ} \mathrm{C}$ (Figures 6 and 7), 


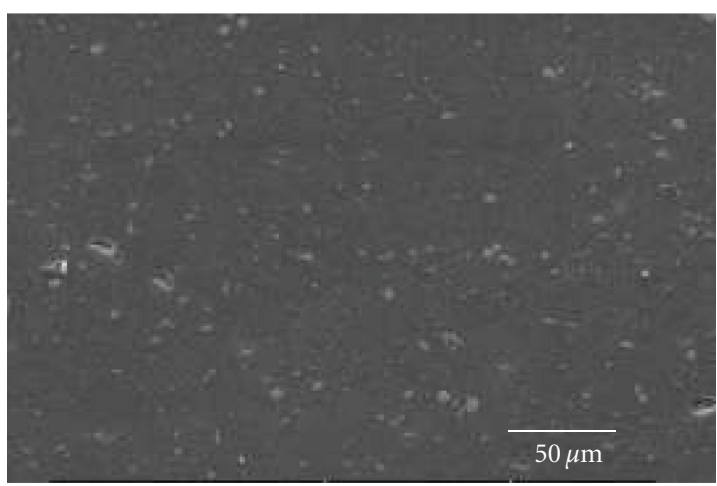

(a)

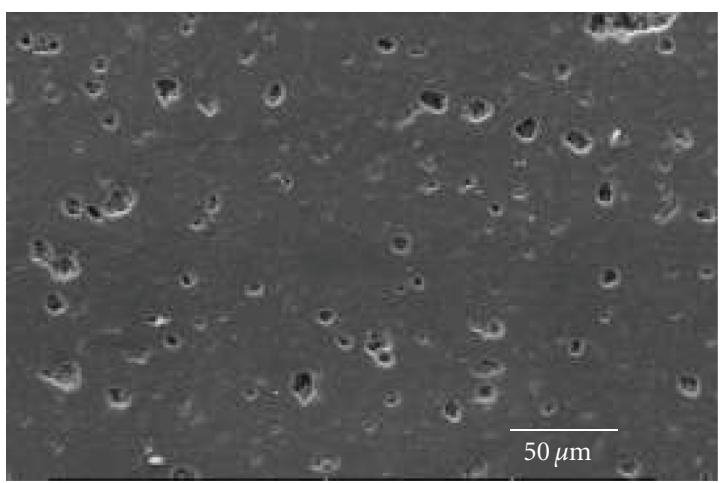

(b)

FIGURE 7: Comparison of microstructure of LZSA laminates (10 layers): $800^{\circ} \mathrm{C}$ (a) and $900^{\circ} \mathrm{C}$ (b).

whereas firing at $900^{\circ} \mathrm{C}$ resulted in ca. $4-5 \%$ decrease in relative density caused by porosity (Figures 6 and 7). This was ascribed to the increased viscosity of the glass system due to crystallization, as mentioned previously. Tapes processed from slurry 5 achieved the high and reproducible relative density values. The highest results of relative density found for tapes from slurry 5 can be attributed to the higher solids content in this formulation. The previous explanation about pores forming due the decrease of relative density and linear shrinkage of the LZSA pellets (Figure 4) can be corroborated by the SEM micrographs in Figure 7.

The tapes of formulation 5 were cofired with stainless steel (AISI 430) at 800 and $900^{\circ} \mathrm{C}$. Neither delamination nor other defect was observed at the LZSA-steel interface at $800^{\circ} \mathrm{C}$, whereas none of the bi-layers remained intact at $900^{\circ} \mathrm{C}$ (Figure 8). Devitrification is believed to be the major cause of the reduced adhesion of LZSA to steel since it causes increased rigidity and porosity of LZSA at high temperature.

\section{Conclusions}

LZSA tapes were prepared and their suitability as alternative seal material for SOFC was tested in terms of its densification characteristics and cofirability with stainless-steel interconnect. The following results were obtained:

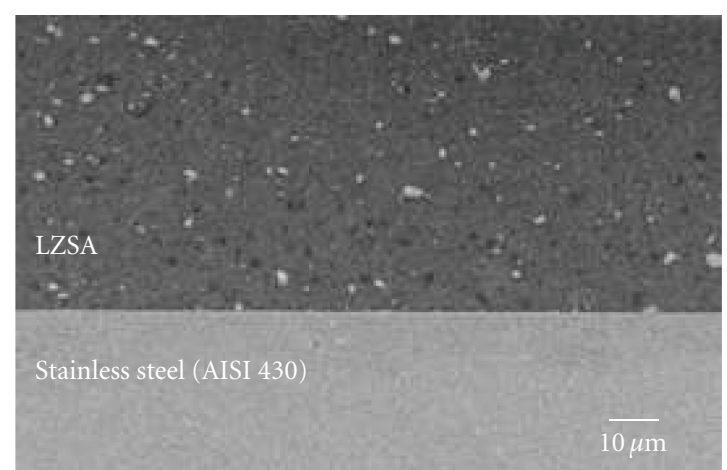

(a)

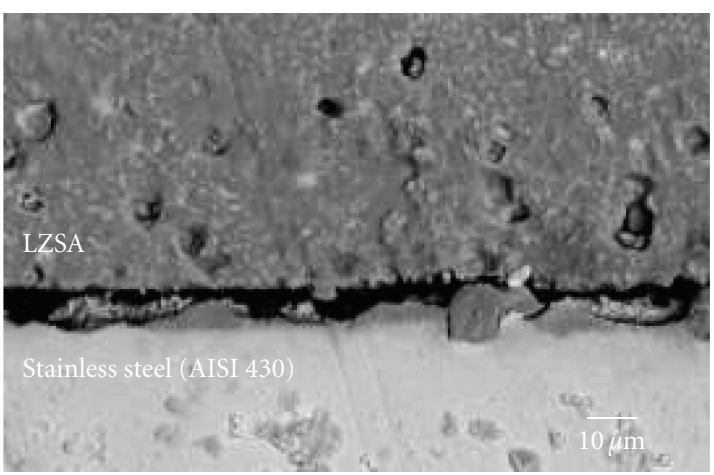

(b)

FIGURE 8: Comparison of interface of cofired LZSA-steel bi-layer: $800^{\circ} \mathrm{C}(\mathrm{a})$ and $900^{\circ} \mathrm{C}(\mathrm{b})$.

(i) LZSA reached a maximum relative density and shrinkage of $95 \%$ and $17 \%$, respectively, at $\sim 800^{\circ} \mathrm{C}$, which was the onset of crystallization as confirmed by DTA. The reduction in density above this temperature was due to crystallization, which increased the viscosity of the system.

(ii) LZSA laminates showed no delamination at interfaces. However, they presented porosity above $800^{\circ} \mathrm{C}$ due to crystallization.

(iii) Cofired LZSA with stainless steel showed an interface free of cracks or delamination at $800^{\circ} \mathrm{C}$, whereas it broke apart from steel at $900^{\circ} \mathrm{C}$. The causes for this failure such as detachment, increased rigidity, and porosity are expected to stem from crystallization.

(iv) Considering the good wetting and defect-free LZSAsteel interface, LZSA can be proposed as an adequate choice of sealing material, particularly for intermediate temperature SOFCs operating under $800^{\circ} \mathrm{C}$.

For complete verification of LZSA as a suitable seal material for SOFC, electrical and chemical characterizations must be finalized, which are the topics of ongoing research. 


\section{Disclosure}

P. Lemes-Rachadel, H. Birol, A. P. N. Oliveira, and D. Hotza are members in the group of Ceramic and Glass Materials (CERMAT).

\section{Acknowledgments}

The authors are grateful to Mr. Guilherme Gregorio, and Mr. Lorenço Neckel, and Mr. Jaime Aguilar for their assistance in preparation of materials and execution of experiments. Brazilian agencies CNPq, CAPES, and FINEP are acknowledged by their financial support.

\section{References}

[1] A. Goel, D. U. Tulyaganov, A. M. Ferrari et al., "Structure, sintering, and crystallization kinetics of alkaline-earth aluminosilicate glass-ceramic sealants for solid oxide fuel cells," Journal of the American Ceramic Society, vol. 93, no. 3, pp. 830$837,2010$.

[2] R. N. Singh, "Sealing technology for solid oxide fuel cells (SOFC)," International Journal of Applied Ceramic Technology, vol. 4, no. 2, pp. 134-144, 2007.

[3] J. W. Fergus, "Sealants for solid oxide fuel cells," Journal of Power Sources, vol. 147, no. 1-2, pp. 46-57, 2005.

[4] B. Zhu, "Next generation fuel cell R\&D," International Journal of Energy Research, vol. 30, no. 11, pp. 895-903, 2006.

[5] B. C. H. Steele and A. Heinzel, "Materials for fuel-cell technologies," Nature, vol. 414, no. 6861, pp. 345-352, 2001.

[6] W. C. J. Wei, "Sealing glass-ceramics for solid oxide fuel cell," Recent Patents on Materials Science, vol. 1, pp. 217-222, 2008.

[7] Z. Yang, G. Xia, K. D. Meinhardt, K. S. Weil, and J. W. Stevenson, "Chemical stability of glass seal interfaces in intermediate temperature solid oxide fuel cells," Journal of Materials Engineering and Performance, vol. 13, no. 3, pp. 327334, 2004.

[8] S. B. Sohn, S. Y. Choi, G. H. Kim, H. S. Song, and G. D. Kim, "Suitable glass-ceramic sealant for planar solid-oxide fuel cells," Journal of the American Ceramic Society, vol. 87, no. 2, pp. 254-260, 2004.

[9] S. S. Parihar, High temperature seals for solid oxide fuel cells [Ph.D. thesis], University of Cincinati, 2006.

[10] Gmelin's Handbook of Inorganic Chemistry, Verlag Chemie, Weinheim, Germany, 1990.

[11] Z. Yang, G. Xia, K. D. Meinhardt, K. S. Weil, and J. W. Stevenson, "Chemical stability of glass seal interfaces in intermediate temperature solid oxide fuel cells," Journal of Materials Engineering and Performance, vol. 13, no. 3, pp. 327334, 2004.

[12] Z. B. Ke, A. X. Lu, and G. F. Huang, "Effect of $\mathrm{K}_{2} \mathrm{O}$ addition on crystallization and microstructure of $\mathrm{Li}_{2} \mathrm{O}-\mathrm{ZnO}-\mathrm{Al}_{2}-\mathrm{SiO}_{2}$ system glass-ceramics," Advanced Materials Research, vol. 1112, pp. 205-208, 2006.

[13] C. M. Gomes, A. P. N. Oliveira, D. Hotza, N. Travitzky, and P. Greil, "LZSA glass-ceramic laminates: fabrication and mechanical properties," Journal of Materials Processing Technology, vol. 206, no. 1-3, pp. 194-201, 2008.

[14] C. R. Rambo, E. De Sousa, A. P. N. Oliveira, D. Hotza, and P. Greil, "Processing of cellular glass ceramics," Journal of the American Ceramic Society, vol. 89, no. 11, pp. 3373-3378, 2006.
[15] T. Hausöl, C. M. Gomes, H. Birol et al., "Corrugated glassceramics from LZSA cast tapes," Journal of Materials Processing Technology, vol. 210, no. 12, pp. 1556-1561, 2010.

[16] L. Giassi, O. R. K. Montedo, D. Hotza, M. C. Fredel, and A. P. N. Oliveira, "Injection moulding of $\mathrm{LiO}_{2}-\mathrm{ZrO}_{2}-\mathrm{SiO}_{2}-\mathrm{Al}_{2} \mathrm{O}_{3}$ (LZSA) glass ceramics," Glass Technology, vol. 46, no. 3, pp. 277-280, 2005.

[17] Powder Diffraction File, Database Sets 1-88, International Centre for Diffration Data (ICDD), Swathmore, Pa, USA, 1993.

[18] L. C. Guo, Y. Zhang, N. Uchida, and K. Uematsu, "Adsorption effects on the rheological properties of aqueous alumina suspensions with polyelectrolyte," Journal of the American Ceramic Society, vol. 81, no. 3, pp. 549-556, 1998.

[19] C. R. Chang and J. H. Jean, "Crystallization kinetics and mechanism of low-dielectric, low-temperature, cofirable $\mathrm{CaO}$ $\mathrm{B}_{2} \mathrm{O}_{3}-\mathrm{SiO}_{2}$ glass-ceramics," Journal of the American Ceramic Society, vol. 82, no. 7, pp. 1725-1732, 1999.

[20] J. S. Reed, Principles of Ceramic Processing, Wiley, New York, NY, USA, 2nd edition, 1995.

[21] R. E. Mistler and E. R. Twiname, Tape Casting-Theory and Practice, The American Ceramic Society, Westerville, Ohio, USA, 2000.

[22] A. C. Pierre and K. Ma, "Sedimentation behaviour of kaolinite and montmorillonite mixed with iron additives, as a function of their zeta potential," Journal of Materials Science, vol. 32, no. 11, pp. 2937-2947, 1997. 

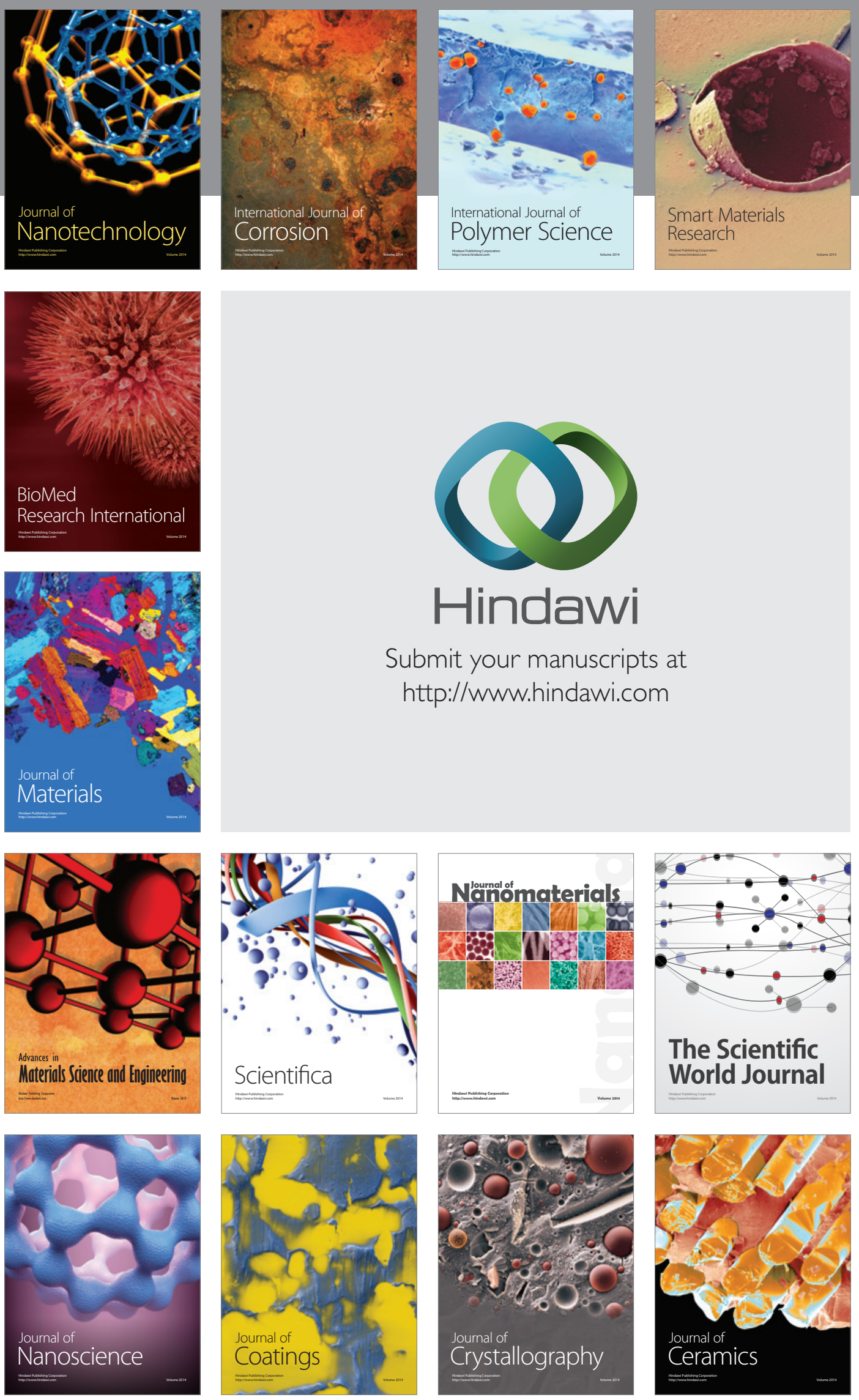

The Scientific World Journal

Submit your manuscripts at

http://www.hindawi.com

\section{World Journal}

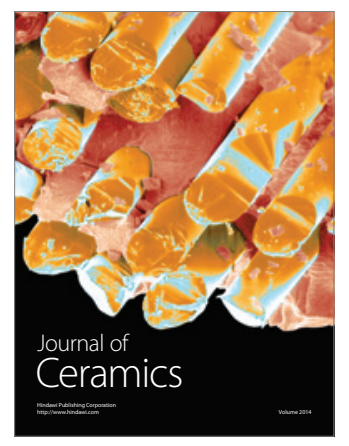

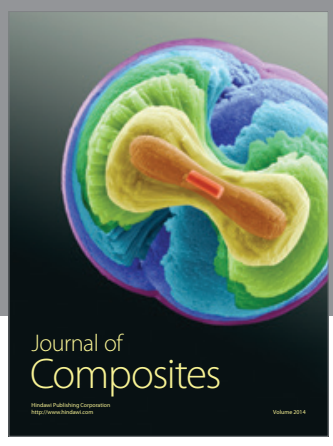
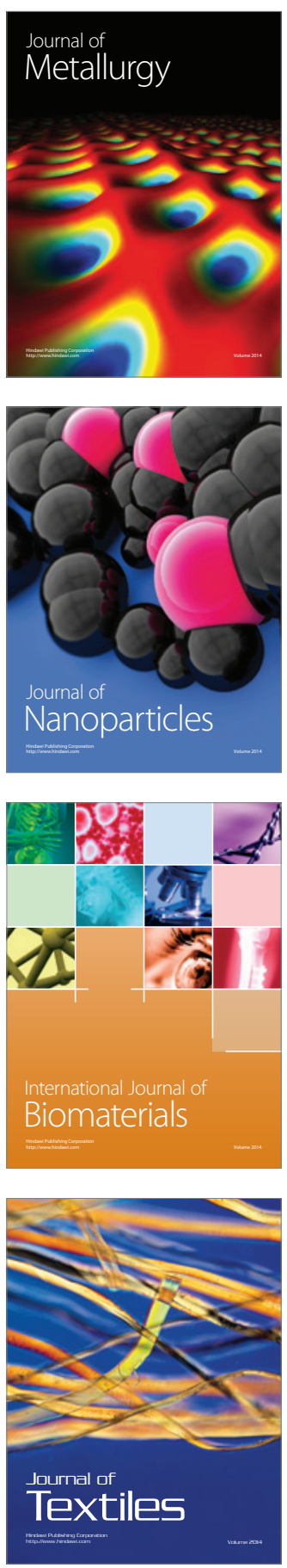